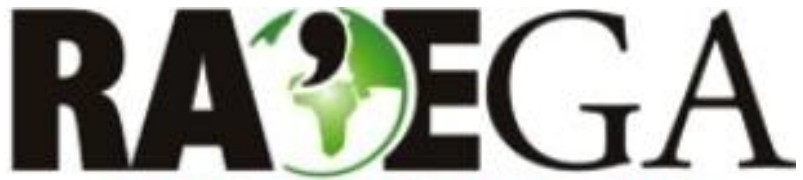

O ESPAÇO GEOGRÁFICO EM ANÁLISE

\title{
ANÁLISE DAS NORMAS AMBIENTAIS FEDERAIS E ESTADUAIS (MG e SC) REFERENTES A EMPREENDIMENTOS DE MINERAÇÃO
}

\author{
ANALYSIS OF ENVIRONMENTAL NORMS FEDERAL AND STATE (MG AND SC) RELATING TO MINING \\ VENTURES \\ Leonardo da Silva Junior ${ }^{1}$, Daniela Rocha Teixeira Riondet Costa르, Maria Inês Nogueira \\ Alvarenga $^{3}$
}

\section{RESUMO}

A mineração é uma das principais atividades realizadas no Brasil, apresentando extremos como o estado de Minas Gerais com a maior extração mineral e o de Santa Catarina com uma produção inferior. Porém, ambos são passíveis de causarem impactos socioambientais. O objetivo deste trabalho, via pesquisa exploratória, foi analisar as normas ambientais referentes a empreendimentos de mineração nas esferas federal e estadual (Minas Gerais e Santa Catarina) em seus aspectos quantitativos e qualitativos. $\mathrm{Na}$ análise qualitativa examinou-se a vertente protecionista, verificando quais normas eram mais restritivas e consequentemente mais protetivas ambientalmente. Ainda, no aspecto qualitativo, averiguou-se a disponibilidade e acessibilidade das normas nos sites de consulta. Constatou-se que Minas Gerais possui o menor número de normas (seis) em relação à União (sete) e ao estado de Santa Catarina (nove). Contudo, tanto o estado mineiro quanto o catarinense apresentam normas semelhantes, no que se refere à vertente protecionista, com distinções mínimas, apesar de explorarem minérios diferentes. Entretanto, ambos os entes federativos instituíram normas com baixo grau de restrição ambiental ou baixa vertente protetiva em relação à Resolução CONAMA 001/86 (Federal), tornando os trâmites ambientais mais simplificados para a exploração do recurso. No que diz respeito à disponibilidade e acessibilidades das normas, o estado de Santa Catarina sobressaiuse ao de Minas Gerais e a União, principalmente na organização e clareza das buscas.

PALAVRAS-CHAVE: Políticas ambientais; Impactos socioambientais; Mineração; Comparação normativa estadual.

\section{ABSTRACT}

Mining is one of the main activities carried out in Brazil, presenting extremes such as the state of Minas Gerais with the largest mineral extraction and Santa Catarina with lower production. However, both are likely to cause socioenvironmental impacts. The objective of this work, through an exploratory research, was to analyze the environmental norms regarding mining enterprises in the federal and state spheres (Minas Gerais and Santa Catarina) in their quantitative and qualitative aspects. In the qualitative analysis the protectionist side was examined, checking which norms were more restrictive and consequently more environmentally protective. Also, in the qualitative aspect, the availability and accessibility of the norms in the research websites was verified. It was found that Minas Gerais has the lowest number of norms (six) compared to the Union (seven) and the state of Santa Catarina (nine). However, both the state of Minas Gerais and the state of Santa Catarina show similar norms regarding the protectionist side, with minimal distinctions, despite the exploitation of different minerals. However, both federative entities instituted norms with a low degree of environmental restriction or low protection in relation to CONAMA Resolution 001/86 (Federal), making the environmental procedures more simplified for the exploitation of the resource. With regard to the availability and accessibility of the norms, the state of Santa Catarina excelled compared to Minas Gerais and the Union, particularly in the organization and clarity of searches.

KEY-WORDS: Environmental Policies; Social and environmental impacts; Mining; State normative comparison.

\section{Recebido em: 12/01/2016}

\footnotetext{
${ }^{1}$ Universidade Federal de Itajubá, UNIFEI, Itajubá/MG, e-mail: mscleonardosj@gmail.com

2 Universidade Federal de Itajubá, UNIFEI, Itajubá/MG, e-mail: daniela.unifei@gmail.com

${ }^{3}$ Universidade Federal de Itajubá, UNIFEI, Itajubá/MG, e-mail: minesalvarenga@gmail.com
} 


\section{ANÁLISE DAS NORMAS AMBIENTAIS FEDERAIS E ESTADUAIS (MG e SC) REFERENTES A EMPREENDIMENTOS DE MINERAÇÃO}

\section{INTRODUÇÃO}

A exploração dos bens naturais foi e continua sendo o alicerce do crescimento econômico e o combustível principal para o desenvolvimento tecnológico. Nesse cenário, demandas de diversas matérias-primas e processos industriais, contribuem para significativa redução dos recursos naturais e, principalmente, causam nocivas modificações ambientais (BORGES; REZENDE; PEREIRA, 2009, p. 449).

Ante esta utilização de recursos naturais, as questões ambientais têm se tornado tema concatenado às políticas públicas. A interferência humana no meio é norteada por normas e regulamentos que inferem adequações estruturais para atender aos limites impostos naturalmente pelo meio ambiente, proporcionando ações antrópicas com preceitos de sustentabilidade. Tal conduta tem amparo no artigo 225 da Constituição Federal (CF) de 1988, o qual determina ser um dever, tanto do Poder Público quanto da sociedade, a promoção de um ambiente ecologicamente equilibrado (BRASIL, 1988).

De acordo com Mickwitz (2006, p. 09), algumas autoridades públicas buscam evitar a degradação e perda de qualidade ambiental e, assim, fazer cumprir a política ambiental. Desta forma, leis, regulamentos, normas, decretos, decisões dos Tribunais, o trabalho dos funcionários públicos incumbidos de elaborar, implementar e fiscalizar atividades antrópicas no meio ambiente, bem como as decisões governamentais de fazer ou deixar de fazer para a proteção do meio ambiente são constituintes básicos da política ambiental (ASSIS, et al., 2012, p. 14).

Sendo assim, os desdobramentos da política ambiental devem estar em sintonia não somente com as características trazidas pelo meio socioambiental, mas sobretudo, com a confluência de adequações compartilhadas pelos entes federados, para determinados empreendimentos em determinadas regiões. $E$ para tal, o poder público local deve atender aos seguintes requisitos: estar em conformidade com a União e o Estado; respeitar os princípios básicos da sustentabilidade e incorporar a sociedade nas tomadas de decisões (RODRIGUES, et al., 2012, p. 97). Segundo Milani (2006, p. 182), a participação pública nos instrumentos que regem a gestão ambiental é primordial e conceituada como progressista já que os diversos atores sociais são conhecedores do meio em questão.

Dentre os empreendimentos de maior relevância para economia nacional e mundial está a mineração, atividade cujo grau de dependência normativa é elevado, devido às peculiaridades presentes em toda etapa de extração mineral. Este empreendimento beneficia a região em que a mesma foi instalada, com a geração de investimentos em infraestrutura, que engloba o transporte, a geração de energia, o saneamento, a pavimentação, a transmissão e a comunicação, sendo ainda polo estratégico de desenvolvimento, pela capacidade de geração de empregos, impostos e compensações financeiras (SANTOS; CARVALHO; FERNANDES, 2010, p. 75). Portanto, a mineração é considerada uma atividade propulsora aos países em desenvolvimento, além de ser vista como melhoria de vida da população que está direta ou indiretamente ligada a tal empreendimento e fundamental para o desenvolvimento da sociedade (FARIAS, 2002, p. 02).

Entretanto, quando não praticada de forma legal e ambientalmente correta, culmina em drásticos impactos ao meio biótico, físico e antrópico, permeando a degradação do ambiente como um todo. Desta maneira, como forma de nortear todas as atividades minerárias no Brasil, diversas normas e regulamentos foram criados, não somente pela União, mas também pelos estados e municípios - que apresentam características sociais, ambientais e econômicas peculiares e são contribuintes para replicação das normas que regulam determinadas atividades minerárias em regiões singulares - já que tanto a 


\section{ANÁLISE DAS NORMAS AMBIENTAIS FEDERAIS E ESTADUAIS (MG e SC) REFERENTES A EMPREENDIMENTOS DE MINERAÇÃO}

mineração quanto as características geoambientais do Brasil apresentam-se, demasiadamente, diversificadas.

Desta forma o objetivo deste trabalho foi analisar as normas ambientais referentes à atividade de mineração nas esferas federal e dos estados de Minas Gerais e Santa Catarina quantitativamente, referente ao número de normas disponíveis sobre o assunto, e discriminar os órgãos ambientais competentes responsáveis pela execução e fiscalização da atividade mineradora. Qualitativamente, buscou-se diagnosticar a vertente protecionista 4, verificando quais normas eram mais restritivas e consequentemente mais protetivas ambientalmente, comparando as normas estaduais com a federal, bem como verificar a disponibilidade e acessibilidade das normas nos sites de consulta.

\subsection{A MINERAÇÃO EM MINAS GERAIS}

A extração mineral em Minas Gerais é destaque na esfera econômica mundial. De acordo com o Instituto Brasileiro de Mineração (IBRAM, 2014, p. 02), o estado mineiro é responsável por aproximadamente $53 \%$ da produção de minerais metálicos e $29 \%$ de minerais em geral para o país, sendo que suas atividades estão presentes em 250 municípios, destacando-se que sete dos dez maiores municípios produtores minerais brasileiros estão no estado de Minas Gerais.

0 estado possui atualmente 300 minas em operação, sendo que no Brasil, Minas Gerais corresponde a cerca de $67 \%$ das minas classe A (extraem valores superiores a 3 milhões t/ano). 0 subsolo mineiro apresenta uma diversidade elevada em relação aos demais estados, sendo os

\footnotetext{
${ }^{4}$ Vertente protecionista: trata das normas que detém maior grau de proteção ao ambiente. Isto é, refere-se à norma que apresenta caráter mais restritivo. Segundo dicionário Aurélio o termo Vertente significa: "aspecto de qualquer coisa que apresenta duas faces opostas ou simplesmente diferentes: A vertente social da ação governamental."

(https://dicionariodoaurelio.com/vertente).
}

principais minérios extraídos da região: bauxita, ferro, manganês, ouro, paládio, prata, dolomito, filito, quartzo, calcário, chumbo, zinco, fosfato, feldspato, granito, zircônio, cobalto, enxofre, níquel, barita, manganês e nióbio. De tal maneira, Minas Gerais nos anos 2011, com 51\% (789 milhões de reais), 2012, com 53\% (975 milhões de reais) e 2013, com 45\% (583 milhões de reais - até junho) ocupou a 1a colocação da arrecadação da CFEM (Compensação Financeira pela Exploração de Recursos Minerais), contribuindo significativamente para a economia nacional (IBRAM, 2014, 14 p).

De acordo com tais dados, Minas Gerais lidera o quadro nacional de exploração mineral devido às suas diversificações, além dos métodos e tecnologias utilizadas para extração e beneficiamento do minério. Porém, devido às más conduções nos processos de regularização ambiental, Minas Gerais torna-se um dos estados mais susceptíveis à perda de qualidade ambiental em relação aos demais (TONIDANDEL, PARIZZI; LIMA, 2012, p. 32).

Desta forma, é imprescindível que o órgão ambiental competente esteja presente nas atividades e todas as fases da extração mineral, de modo a conhecer os impactos negativos gerados, permitindo ao Estado influenciar as políticas ambientais de maneira significativa, a fim de reduzir ao máximo os danos socioambientais (FEAM, 2011, p. 12).

Em Minas Gerais, o órgão competente pelo licenciamento de mineração é o Conselho Estadual de Política Ambiental (COPAM), que atribuiu competência às Superintendências Regionais de Meio Ambiente e Desenvolvimento Sustentável (SUPRAM's), às Unidades Regionais Colegiadas (URC's), à Fundação Estadual de Meio Ambiente (FEAM) e ao Instituto Estadual de Florestas (IEF) para licenciar tais empreendimentos, de acordo com a regionalização em que as atividades se encontram, de modo a descentralizar e dinamizar o processo de licenciamento ambiental (MINAS GERAIS, 2006, p. 02).

De tal maneira, a alta demanda por mineração no estado acaba envolvendo diversos 


\section{ANÁLISE DAS NORMAS AMBIENTAIS FEDERAIS E ESTADUAIS (MG e SC) REFERENTES A EMPREENDIMENTOS DE MINERAÇÃO}

aspectos negativos para as políticas públicas de sustentabilidade. Como observado por Fabri, Carneiro e Leite (2008, p. 281) em 130 empreendimentos minerários em Minas Gerais, cerca de $40 \%$ deles funcionavam sem Licença de Instalação (LI) e Licença de Operação (LO) e não apresentaram medidas mitigadoras para os impactos detectados, além de não serem fiscalizados pela FEAM, quando os mesmos obtiveram as licenças exigidas.

De acordo com Viana (2007, p. 17), quanto ao aspecto normativo ambiental, os estados brasileiros, principalmente Minas Gerais, elaboraram e continuam elaborando normas próprias, o que muitas vezes acaba sendo conflitante com as normas da União no que se refere à vertente protecionista.

\subsection{A MINERAÇÃO EM SANTA CATARINA}

A extração mineral em Santa Catarina caracteriza-se pelas explorações nas regiões carboníferas, onde no período Permiano, o carbono se acumulou no solo em virtude da decomposição das grandes florestas, através, da perda de hidrogênio e oxigênio (GERÔNIMO, 2004, p. 08). Contudo, o carvão mineral basicamente é uma rocha sedimentar, produto de atividades posteriores à deposição de materiais orgânicos de vegetais, onde consequentemente tal material passa por um processo de transformação, resultando em turfa (55\% de carbono), linhito (70\% de carbono), hulha ( $80 \%$ de carbono) e o antracito (90\% de carbono) (YAMAGUCHI; SORATTO; MARIOT, 2014; MONTEIRO, 2004, p. 229). De tal forma, a região Sul brasileira é abundantemente rica em carvão mineral, principalmente 0 estado catarinense, ocupando uma posição única em relação à produção de carvão no Brasil, pois o mesmo representa $59 \%$ da produção deste minério em âmbito federal, obtendo no ano de 2011 um faturamento de aproximadamente 453,6 milhões de reais (FIESC, 2013, p. 72).

Segundo o IBRAM (2012, p. 14) o estado catarinense representa $0,19 \%$ do investimento do setor mineral brasileiro de 2012 a 2016, correspondendo à uma quantia de US\$ 146 mil.
Tal valor torna-se insignificante quando se compara com a diversidade mineral produzida em solo mineiro, onde, o estado corresponde a $35 \%$ do investimento (US\$ 26.160.139, 73) para o mesmo período.

Entretanto, o estado catarinense não está isento de políticas ambientais e fiscalizações incoerentes, o que acaba resultando em prejuízos socioambientais. As peculiaridades da extração do carvão permitem que o mesmo seja lavrado em minas subterrâneas ou a céu aberto, sendo este último, responsável pelas maiores degradações ambientais, por meio dos rejeitos e do revolvimento de solo fértil e estéril que acaba comprometendo as posteriores etapas de compensação ambiental (ALEXANDRE, 1999, p. 41). De tal maneira, verifica-se uma incompatibilidade entre órgãos governamentais, a sociedade e o meio ambiente, o que vem acarretando diversos conflitos para a política ambiental.

No estado catarinense, de acordo com a Resolução CONSEMA 001/2006, compete à Fundação de Meio Ambiente (FATMA), a execução dos processos de licenciamento ambiental de atividades consideradas causadoras de degradação ambiental, nos quais a extração mineral está inserida (CONSEMA, 2006, p. 01).

De acordo com Bandeira (2006, p. 29), mesmo os estados apresentando diversas políticas econômicas e estarem com o setor equilibrado, ainda observa-se uma crise entre políticas ambientais da união e dos estados, verificando-se falta de interação entre o órgão governamental e a sociedade civil, o que acarreta em políticas insustentáveis tanto a nível ambiental quanto social.

\subsection{IMPACTOS ASSOCIADOS À MINERAÇÃO}

Impacto ambiental é um conceito bastante amplo e pode ser empregado a qualquer alteração do meio e seus componentes (SÁNCHEZ, 2013, p. 29). Alguns autores conceituam o termo "impacto ambiental" como qualquer alteração do meio, atingindo pelo menos um de seus componentes, sendo produto de atividades ou ações humanas ou a mudança 


\section{ANÁLISE DAS NORMAS AMBIENTAIS FEDERAIS E ESTADUAIS (MG e SC) REFERENTES A EMPREENDIMENTOS DE MINERAÇÃO}

espaço-temporal de um parâmetro ambiental, resultante de uma ação antrópica, comparado com a mesma mudança, porém quando a mesma se deu de forma natural, ou seja, sem interferência humana (WATHERN, 1988, p. 7).

Deste modo, a mineração caracteriza-se por ser umas das atividades mais impactantes do setor primário, sendo responsável por alterações socioambientais desde o início da exploração até à fase de fechamento, onde seus rejeitos apresentam riscos nocivos ao meio ambiente. A mineração de modo geral traz complicações em relação à paisagem, ou seja, modificam toda a estrutura ecossistêmica e dinâmica natural, tornando a região afetada um local estéril, além de agredir direta e indiretamente a biota e ocupação humana com ruídos, vibrações e trafego de veículos (SOUZA SILVA, 2007, p. 06).

De acordo com o IBAMA (2002, p. 71) os agravantes que mais se destacam na exploração do minério são: poluição da água, poluição do ar, poluição sonora, subsidência de terreno, disposição dos rejeitos, impactos sobre a biodiversidade, além de riscos sociais dos moradores que residem nas proximidades das minas e barragens de contenção.

Quanto aos estados estudados, em Minas Gerais, segundo Souza Silva (2007, p. 04), a extração do ouro no Quadrilátero Ferrífero trouxe diversos impactos, principalmente aos riachos localizados na região, que recebiam frequentemente os rejeitos de minério ricos em arsênio comprometendo a qualidade tanto da água quanto do solo.

Fabri, Carneiro e Leite (2008, p. 281) registraram em seu estudo sobre o licenciamento de pedreiras da região centro-sul de Minas Gerais, que os principais problemas dessas atividades são perturbação da superfície, remoção da vegetação, remoção do solo, geração e disposição inadequada dos rejeitos em áreas de bota-fora, abertura de estradas mal planejadas, imposição de superfícies diferentes do relevo original, degradação do entorno, principalmente em áreas de empréstimos de solos, liberação de poeira e a geração de poluição sonora. Analogamente, Guimarães et al. (2012, p. 07) realizaram um estudo no Município de Poços de Caldas no Sul de Minas Gerais e observaram que o impacto visual é com certeza o que mais se destaca ao observar uma mineração, porém, o principal impacto verificado são os danos à biodiversidade florestal.

Perante tais estudos, é relevante mencionar o desastre ocorrido no município de Mariana-MG. Duas barragens de rejeitos de minério de ferro se romperam e culminou em um avalanche deste material, percolando-se aos municípios à jusante, destruindo bens e patrimônios culturais, até atingir as águas do Rio Doce. Consequentemente, toda substância de origem mineral, chegou ao estado do Espirito Santo, até atingir o litoral, comprometendo significativamente toda biota, recursos abióticos e populações humanas.

Já no estado catarinense com a exploração do carvão mineral, que abrange grandes áreas, há acometimento peculiar de impactos nos recursos hídricos, no solo e no ar. A infiltração das águas pluviométricas sobre o rejeitos de carvão na região alcançam os corpos hídricos subterrâneos ou superficiais, tornando os mesmos ácidos, impedindo seu uso e prejudicando a flora e fauna aquática (IBAMA, 2002, p. 70).

Amaral et al., (2011, p. 16) realizaram uma pesquisa no município de Criciúma-SC, comparando os impactos da mineração de carvão em uma área urbana e rural. Os autores observaram que na área urbana, os domicílios e vias foram construídos sobre as pilhas de rejeitos carbonosos e sobre as bocas de minas aterradas pela construção civil e na área rural foram identificadas 10 bocas de minas abandonadas em uma Área de Preservação Permanente (APP5) onde uma delas apresentava drenagem ácida de mina em função dos rejeitos à montante. $O$ contato do minério bruto de carvão extraído com

\footnotetext{
5 APP: área protegida, coberta ou não por vegetação nativa, com a função ambiental de preservar os recursos hídricos, a paisagem, a estabilidade geológica e a biodiversidade, facilitar o fluxo gênico de fauna e flora, proteger o solo e assegurar o bem-estar das populações humanas - (BRASIL, 2012, p. 3).
} 


\section{ANÁLISE DAS NORMAS AMBIENTAIS FEDERAIS E ESTADUAIS (MG e SC) REFERENTES A EMPREENDIMENTOS DE MINERAÇÃO}

a água proporciona um carreamento desta sinergia química alterando a qualidade físicoquímica dos corpos d'água à jusante (UBALDO; SOUZA, 2008, p. 135). Tal impacto trazido pela extração de carvão no estado catarinense se deve ao $\mathrm{pH}$ baixo $(<3)$ e metais dissolvidos, os quais são resultados de processos químicos e biológicos oriundos da exposição de minerais sulfetados em conjunto com água e oxigênio (WEl et al., 2008, p. 3276).

Philomena, Follmann e Gonçalves (2012, p. 254) diagnosticaram também em Criciúma, que há conflitos socioambientais devido à economia do carvão ser um processo questionável. Isso se deve à maneira com que tal atividade é vista na região, pois a extração mineral no estado sempre foi vista como progresso e desenvolvimento, porém o que se pode observar em relação aos aspectos sociais e ambientais é que o processo de extração do carvão é altamente nocivo, sendo o mesmo um combustível fóssil, além de emitir grandes quantidades de dióxido de carbono e material particulado, afetando de maneira abusiva a qualidade do ar.

De tal forma, as fases da mineração são peculiares para cada tipo de impacto ambiental durante o processo de extração. A etapa de abertura da cava traz consequências como: perda de biodiversidade florestal, desestruturação do solo e alteração da paisagem. Por outro lado o uso de explosivos em pedreiras pode acarretar vibração do terreno, lançamento de fragmentos, ruídos, gases e poeiras, assim como a etapa de transporte e beneficiamento que culminam ainda em impactos sobre corpos d'água, solo, ar e população local (BACCI; LANDIM; ESTON, 2006, p. 48).

\section{MATERIAIS E MÉTODOS}

O trabalho caracterizou-se como pesquisa exploratória, na qual se buscou proporcionar maior familiaridade com o problema, para maior conhecimento ou para construir hipóteses. Também realizou-se pesquisas bibliográficas e documentais sobre temas já discutidos por outros autores. Assim, a condução da pesquisa procedeu-se abordando aspectos quantitativos e qualitativos, a fim de verificar grandezas e comportamentos do arcabouço regulatório de cada ente federativo (GIL, 2008, p. 27; KAUARK; MANHÃES; MEDEIROS, 2010, p. 24; SOUZA, et al., 2013, p. $15 ;)$.

O levantamento quantitativo das normas ambientais referentes à mineração para a União e para os estados de Minas Gerais e Santa Catarina foi realizado por meio de pesquisa documental através do banco de dados disponibilizado virtualmente pelos órgãos ambientais, pelas Assembleias Legislativas dos respectivos estados e pelo Senado no que se refere à União. Posteriormente as normas foram discriminadas em um quadro de modo a quantificar as normas dos entes federativo e estaduais.

A discriminação dos órgãos ambientais competentes foi realizada por meio de pesquisas nas normas consultadas para cada ente federativo, onde a mesma foi realizada, através de buscas nos sites ${ }^{6}$ do portal do Ministério do Meio Ambiente, Portal da Câmara dos Deputados, Portal do Planalto, Portal da Assembleia Legislativa de Minas Gerais, Portal do Sistema Integrado de Informação Ambiental (SIAM) de Minas Gerais, Portal da SEMAD, Portal da Assembleia Legislativa de Santa Catarina, Portal da FATMA, Portal da Fundação de Meio Ambiente de Criciúma (FAMCRI) e o Portal da Secretaria de Desenvolvimento Sustentável de Santa Catarina. Posteriormente os mesmos foram elencados de forma a quantificar quais órgãos ambientais são responsáveis pela execução e fiscalização da atividade mineradora.

Em relação à análise qualitativa das normas, as mesmas foram analisadas para diagnosticar a vertente protecionista, verificando quais normas eram mais restritivas $\mathrm{e}$

\footnotetext{
${ }^{6}$ Sites consultados: www.mma.gov.br; www2.camara.leg.br; www2.planalto.gov.br; www.siam.mg.gov.br; www.alesc.sc.gov.br; www.famcri.sc.gov.br; www.sds.sc.gov.br
} 


\section{ANÁLISE DAS NORMAS AMBIENTAIS FEDERAIS E ESTADUAIS (MG e SC) REFERENTES A EMPREENDIMENTOS DE MINERAÇÃO}

consequentemente mais protetivas ambientalmente, comparando as normas estaduais com a federal, de modo a verificar o nível de restrição dos estados estudados. 0 mesmo procedimento se deu para verificar a disponibilidade e acessibilidade das normas nos sites de consulta.

Vale ressaltar que todas as normas analisadas foram conceituadas como genéricas para o tema meio ambiente e mineração, não sendo consideradas normas especificas para determinados tipos de mineração.

\section{RESULTADOS E DISCUSSÕES}

No que se refere às questões ambientais, existe a possibilidade de se ter normas nas três esferas do poder: Federal, Estadual e Municipal, bem como aquelas vinculadas aos órgãos ambientais.

$\mathrm{O}$ artigo 22 da Constituição Federal traz que é competência privativa da União legislar sobre a exploração de recursos minerais, podendo haver a delegação desta exploração para os demais entes federativos - estados. Mas, no que se refere aos casos de proteção dos recursos naturais, a competência legislativa é concorrente (art. 24), ou seja, atribuída a todos os entes federados. Sendo que, para se evitar conflitos de normas, a União se limita a estabelecer normas gerais.

Quando se fala que os órgãos ambientais também editam normas, trata-se de uma forma de se preencher lacunas. A partir do momento em que Poder Legislativo deixa de legislar sobre um determinado assunto o órgão ambiental pode, via Resoluções ou Instruções Normativas por exemplo - suprir essa falta.

Neste estudo tem-se a presença das duas competências - privativa e concorrente -, pois o assunto abordado envolve mineração e proteção dos recursos naturais, bem como das normas estabelecidas pelos órgãos ambientais, visto que a matéria não fora totalmente regulamentada pelo Poder Legislativo.

Sendo assim, os quadros 1, 2 e 3 trazem as normas ambientais federais e estaduais (MG e SC), aplicadas aos empreendimentos de mineração de forma genérica, tratando da proteção dos recursos ambientais envolvidos na atividade e regulamentação da mineração em geral.

Quadro 01 - Cronologia das normas legais sobre a mineração em âmbito Federal.

\begin{tabular}{|c|c|c|}
\hline Norma & Conteúdo & Fonte \\
\hline $\begin{array}{l}\text { Decreto Lei Federal } n=227 \text {, de } 28 \\
\text { de fevereiro de } 1967 .\end{array}$ & $\begin{array}{l}\text { Dispõe sobre o Código Nacional de } \\
\text { Mineração. }\end{array}$ & $\begin{array}{l}\text { http://www.planalto.gov.br/cci } \\
\text { vil_03/decreto-lei/del0227 }\end{array}$ \\
\hline $\begin{array}{l}\text { Resolução Conama no 1, de } 23 \\
\text { de janeiro de } 1986 .\end{array}$ & $\begin{array}{l}\text { Dispõe sobre critérios básicos e diretrizes } \\
\text { gerais para a avaliação de impacto } \\
\text { ambiental. }\end{array}$ & $\begin{array}{l}\text { http://www.mma.gov.br/port/ } \\
\text { conama/legiabre.cfm?codlegi= } \\
23\end{array}$ \\
\hline $\begin{array}{l}\text { Decreto } n=97.507 \text {, de } 13 \text { de } \\
\text { fevereiro de } 1989 \text {. }\end{array}$ & $\begin{array}{l}\text { Dispõe sobre licenciamento de atividade } \\
\text { mineral, o uso do mercúrio metálico e do } \\
\text { cianeto em áreas de extração de ouro, e dá } \\
\text { outras providências. }\end{array}$ & $\begin{array}{l}\text { http://www.planalto.gov.br/cci } \\
\text { vil_03/decreto/1980- } \\
\text { 1989/D97507.htm }\end{array}$ \\
\hline $\begin{array}{l}\text { Decreto no 97.632, de } 10 \text { de abril } \\
\text { de } 1989 .\end{array}$ & $\begin{array}{l}\text { Dispõe sobre a regulamentação do Artigo } 2^{\circ} \text {, } \\
\text { inciso VIII, da Lei }{ }^{\circ} 6.938 \text {, de } 31 \text { de agosto } \\
\text { de } 1981 \text {, e dá outras providências. }\end{array}$ & $\begin{array}{l}\text { http://www.planalto.gov.br/cci } \\
\text { vil_03/decreto/1980- } \\
\text { 1989/D97632.htm }\end{array}$ \\
\hline $\begin{array}{l}\text { Lei no } 7.805 \text {, de } 18 \text { de julho de } \\
1989 .\end{array}$ & $\begin{array}{l}\text { Altera o Decreto-Lei no } 227 \text {, de } 28 \text { de } \\
\text { fevereiro de 1967, cria o regime de } \\
\text { permissão de lavra garimpeira, extingue o } \\
\text { regime de matrícula, e dá outras } \\
\text { providências. }\end{array}$ & $\begin{array}{l}\text { http://www.planalto.gov.br/cci } \\
\text { vil_03/Leis/L7805.htm }\end{array}$ \\
\hline $\begin{array}{l}\text { Resolução Conama no 237, de } 19 \\
\text { de dezembro de } 1997 .\end{array}$ & $\begin{array}{l}\text { Dispõe sobre a revisão e complementação } \\
\text { dos procedimentos e critérios utilizados para } \\
\text { o licenciamento ambiental. }\end{array}$ & $\begin{array}{l}\text { http://www.mma.gov.br/port/ } \\
\text { conama/res/res97/res23797.ht } \\
\mathrm{ml}\end{array}$ \\
\hline Lei no 11.685 , de 2 de junho de & Institui o Estatuto do Garimpeiro e dá outras & http://www.planalto.gov.br/cci \\
\hline
\end{tabular}




\section{ANÁLISE DAS NORMAS AMBIENTAIS FEDERAIS E ESTADUAIS (MG e SC) REFERENTES A EMPREENDIMENTOS DE MINERAÇÃO}

\begin{tabular}{|l|l|l|}
\hline 2008 & providências. & $\begin{array}{l}\text { vil_03/_Ato2007- } \\
\text { 2010/2008/Lei/L11685.htm }\end{array}$
\end{tabular}

As normas ambientais federais referentes ao setor de mineração são representadas atualmente por sete regulamentações, distribuídas em duas (02) Leis, três (03) Decretos e duas (02) Resoluções, totalizando sete (07) normas. Pode-se observar que as primeiras normas federais analisadas quanto aos empreendimentos de mineração são datadas principalmente da década de 1980, período em que as normas ambientais brasileiras tinham uma maior cobrança devido à instituição da Política Nacional de Meio Ambiente - PNMA, Lei 6.938, de 1981, que tem por objetivo a preservação, melhoria e recuperação da qualidade ambiental propícia à vida, assegurar condições ao desenvolvimento socioeconômico, aos interesses da segurança nacional e à proteção da dignidade da vida humana. Contudo, foi possível encontrar normas federais relacionadas ao assunto, desde o século XIX, quando a mineração nacional começou a afetar positivamente a economia do país, porém, ainda não se mencionavam as preocupações ambientais.

A primeira norma, o Código de Mineração de 1967, confere competência executiva ao DNPM, ou seja, este órgão ficou responsável por promover o planejamento e o fomento da exploração mineral; o aproveitamento dos recursos minerais; suas pesquisas geológicas, bem como assegurar, controlar e fiscalizar o exercício das atividades de mineração em todo o território nacional. A partir de então, com a instauração desta regulamentação, cujo objetivo era difundir as responsabilidades e deveres de órgãos competentes do setor e das empresas, principalmente com a implantação das etapas e regimes a serem cumpridos para autorização de lavra é que se iniciavam as preocupações com o setor mineral quanto às diretrizes de concessão e administração das minas nacionais.

Posteriormente ao Código de Mineração e a PNMA, em 1986, por meio da Resolução CONAMA 001, instituíram-se as diretrizes da avaliação de impacto ambiental (AIA). A
Resolução CONAMA 001/86 determina a competência dos órgãos integrantes do Sistema Nacional de Meio Ambiente (SISNAMA), tendo como braço executivo o IBAMA a nível federal e os respectivos órgãos competentes de cada estado, para fazer cumprir as regulamentações sobre a AIA, onde a mineração é um dos empreendimentos inseridos, que deve apresentar Estudo de Impacto Ambiental (EIA) em qualquer região ou estado do país. Cabe relembrar que a competência para legislar sobre matéria de proteção de recursos naturais é concorrente de todos os órgãos da federação.

Contudo, três anos mais tarde em 1989, surge o Decreto 97.507, que dispõe sobre o licenciamento ambiental em minerações e regulamenta o uso indevido de mercúrio e cianeto em áreas de lavra do ouro em território nacional. No mesmo ano, foi também instituído o Decreto 97.632, que dispõe sobre a obrigatoriedade da proposição conjunta aos EIAs/RIMAs, da elaboração e execução do Plano de Recuperação de Áreas Degradadas (PRAD), especificamente para mineração em qualquer localidade do território nacional. Para ambos os Decretos, os órgãos ambientais estaduais têm competência executiva para determinar o uso do mercúrio e do cianeto em áreas de extração de ouro bem como das diretrizes para elaboração do PRAD.

A norma seguinte é a Lei 7.805/89, de competência executiva do DNPM, que outorga a permissão de lavra garimpeira de substâncias minerais garimpáveis. De tal forma, os empreendimentos de mineração até então começavam a nortear-se para as questões ambientais e eram obrigados após o término do lavramento, recuperar e monitorar a área que foi degradada. Esta obrigatoriedade ganhou mais intensidade a partir de 1997, com a implantação da Resolução CONAMA 237, que visa complementar os procedimentos de licenciamento ambiental, no qual, compete às três esferas federativas (União, Estados e Municípios), quando a atividade se enquadrar nas 


\section{ANÁLISE DAS NORMAS AMBIENTAIS FEDERAIS E ESTADUAIS (MG e SC) REFERENTES A EMPREENDIMENTOS DE MINERAÇÃO}

conformidades previstas de acordo com o art. 4 은 desta resolução.

A mineração é passível de licenciamento ambiental tendo que possuir as Licenças Prévia (LP), de Instalação (LI) e de Operação (LO) para realizar suas atividades. Contudo, em 2008 por meio da Lei 11.685 , de competência executiva do DNPM, foi instituído o estatuto do garimpeiro, onde a norma regula os direitos e deveres dos trabalhadores que estão diretamente ligados à extração de minério, estando o mesmo obrigado, como previsto anteriormente, a recuperar as áreas degradadas, de acordo com o art. 120 desta lei.

No que se refere à disponibilidade e acessibilidade das normas nos sites de consulta, pode-se observar que todas as regulamentações estão disponíveis. Porém a acessibilidade no Portal do Ministério do Meio Ambiente e Portal do Planalto não se apresentam clara e objetiva, demandando mais tempo às buscas. Nestes sites os resultados das consultas são ordenados de maneira genérica abrangendo diversos temas incoerentes com a pesquisa específica. Já o Portal da Câmara dos Deputados, a busca por qualquer assunto normativo é claro e objetivo, listando instantaneamente em ordem cronológica todas as regulamentações quanto ao assunto requerido. Ante este levantamento verificou-se que o Princípio da Informação, um dos pilares do Direito Ambiental, está sendo cumprido em parte.

Quadro 02 - Cronologia das normas legais sobre a mineração em Minas Gerais.

\begin{tabular}{|c|c|c|}
\hline Norma & Conteúdo & Fonte \\
\hline $\begin{array}{l}\text { Lei no } 10.595 \text {, de } 07 \text { de janeiro } \\
\text { de } 1992 .\end{array}$ & $\begin{array}{l}\text { Proíbe a utilização de mercúrio e cianeto de } \\
\text { sódio nas atividades de pesquisa mineral, } \\
\text { lavra e garimpagem nos rios e cursos de água } \\
\text { do Estado e dá outras providências. }\end{array}$ & $\begin{array}{l}\text { http://www.almg.gov.br/consul } \\
\text { te/legislacao/completa/comple } \\
\text { ta.html?tipo=LEI\&num=10595\& } \\
\text { comp=\&ano=1992 }\end{array}$ \\
\hline $\begin{array}{l}\text { Deliberação Normativa Copam } \\
\text { no } 74 \text {, de } 09 \text { de setembro de } \\
2004\end{array}$ & $\begin{array}{l}\text { Estabelece critérios para classificação, } \\
\text { segundo o porte e potencial poluidor, de } \\
\text { empreendimentos e atividades } \\
\text { modificadoras do meio ambiente passíveis } \\
\text { de autorização ambiental de funcionamento } \\
\text { ou de licenciamento ambiental no nível } \\
\text { estadual, determina normas para } \\
\text { indenização dos custos de análise de pedidos } \\
\text { de autorização ambiental e de licenciamento } \\
\text { ambiental, e dá outras providências. }\end{array}$ & $\begin{array}{l}\text { http://sisemanet.meioambient } \\
\text { e.mg.gov.br/mbpo/recursos/De } \\
\text { liberaNormativa74.pdf }\end{array}$ \\
\hline $\begin{array}{l}\text { Decreto no } 44.309 \text {, de } 5 \text { de junho } \\
\text { de } 2006\end{array}$ & $\begin{array}{l}\text { Estabelece normas para o licenciamento } \\
\text { ambiental e a autorização ambiental de } \\
\text { funcionamento, tipifica e classifica as } \\
\text { infrações às normas de proteção ao meio } \\
\text { ambiente e aos recursos hídricos e } \\
\text { estabelece o procedimento administrativo de } \\
\text { fiscalização e aplicação das penalidades. }\end{array}$ & $\begin{array}{l}\text { http://www.siam.mg.gov.br/sla } \\
\text { /download.pdf?idNorma=5607 }\end{array}$ \\
\hline $\begin{array}{l}\text { Deliberação Normativa Copam } \\
\text { no } 127 \text {, de } 27 \text { de novembro de } \\
2008\end{array}$ & $\begin{array}{l}\text { Estabelece diretrizes e procedimentos para } \\
\text { avaliação ambiental da fase de fechamento } \\
\text { de mina. }\end{array}$ & $\begin{array}{l}\text { http://www.siam.mg.gov.br/sla } \\
\text { /download.pdf?idNorma=8732 }\end{array}$ \\
\hline $\begin{array}{l}\text { Deliberação Normativa Copam } \\
\text { no } 144 \text {, de } 18 \text { de dezembro de } \\
2009\end{array}$ & $\begin{array}{l}\text { Dispõe sobre a declaração de informações } \\
\text { relativas à identificação e classificação de } \\
\text { áreas mineradas detentoras de Autorização } \\
\text { Ambiental de Funcionamento - AAF no } \\
\text { Estado de Minas Gerais. }\end{array}$ & $\begin{array}{l}\text { http://www.siam.mg.gov.br/sla } \\
\text { /download.pdf?idNorma=1261 } \\
9\end{array}$ \\
\hline $\begin{array}{l}\text { Deliberação Normativa Copam } \\
\text { no } 145 \text {, de } 18 \text { de dezembro de } \\
2009\end{array}$ & $\begin{array}{l}\text { Dispõe sobre a declaração de informações } \\
\text { relativas à identificação e classificação de } \\
\text { áreas mineradas abandonadas no Estado de } \\
\text { Minas Gerais. }\end{array}$ & $\begin{array}{l}\text { http://www.siam.mg.gov.br/sla } \\
\text { /download.pdf?idNorma=1262 } \\
1\end{array}$ \\
\hline
\end{tabular}


Em Minas Gerais, as normas que regulamentam a mineração estão distribuídas em uma (01) Lei, um (01) Decreto e quatro (04) Deliberações Normativas (DN) do COPAM, órgão normativo, consultivo e deliberativo de Minas Gerais, totalizando seis (06) normas. A primeira norma instituída no estado mineiro em relação à mineração foi a Lei 10.595/02, cuja competência executiva cabe ao COPAM. Esta Lei complementa o Decreto Federal 97.507/89, sobre a utilização do mercúrio e cianeto nas atividades minerais em corpos d'água. Neste caso a norma mineira foi mais protetiva, sendo mais restritiva do que a federal, proibindo o uso do mercúrio e cianeto nas atividades de pesquisa mineral, lavra e garimpagem no leito e nas margens dos rios e cursos de água do Estado. Aqui cabe relembrar que não é obrigatória que uma norma estadual seja mais restritiva que uma federal, o que ela não pode ser é mais permissiva. Portanto, o estado de MG foi além do que é pedido no que se refere à proteção ambiental.

Posteriormente em 2004, o COPAM, instituiu a DN 74, atribuindo competência aos órgãos regionais do estado para licenciar, administrar e fiscalizar todos os trâmites ambientais do estado. De acordo com tal normativa, os empreendimentos podem se enquadrar em seis classes distintas que variam de 1 a 6 , em conformidade com o porte e potencial poluidor degradador. As classes 1 e 2 são empreendimentos sujeitos apenas à Autorização Ambiental de Funcionamento (AAF), as classes 3 e 4, são os empreendimentos sujeitos à Relatório de Controle Ambiental e Plano de Controle Ambiental (RCA/PCA) e as classes 5 e 6 são os empreendimentos sujeitos ao EIA/RIMA. A norma apresenta um anexo peculiar, relatando os diversos tipos de mineração, bem como o porte e potencial poluidor degradador de cada atividade. Contudo, esta classificação adotada pelo estado conflita diretamente com a resolução CONAMA 001/86 que enquadra todo tipo de mineração passiva de EIA/RIMA, sendo a norma mineira menos restritiva possibilitando estudos menos detalhados para alguns empreendimentos de mineração.
Entretanto, a DN 74/04 não dispunha de penalidades e procedimentos administrativos para fiscalização, sendo então estabelecido em 2006 o Decreto Estadual 44.309, que atribuiu competência executiva aos órgãos regionais do estado. Contudo, Minas Gerais assegurou a viabilidade ambiental pós fechamento de minas através da DN 127/08 que estabelece critérios e diretrizes para o PRAD, tratando especificamente do Plano Ambiental de Fechamento de Mina (PAFEM), sendo de competência das URC's e COPAM a análise técnica dos planos. Ambos órgãos possuem responsabilidade por monitorar e fiscalizar a recuperação das áreas degradadas pelo empreendimento. Esta normativa está em acordo com a federal, pois, apresenta maiores restrições ao empreendedor do estado de Minas Gerais, já que a norma Federal não especifica quais procedimentos devem ser adotados ao elaborar um PRAD, por trazer uma visão geral, de acordo com o que determina a doutrina.

Apesar de estar em concordância com norma a federal, pode-se destacar que Minas Gerais ainda apresenta regulamentos que conflitam diretamente com normas federais, como a DN 144 de 2009, que trata dos empreendimentos de mineração detentores de AAF e suas diretrizes. Como observado anteriormente, a AAF é um tipo de licenciamento ambiental, porém bem mais simplificado não sendo exigidos estudos ambientais detalhados, o que se opõe à norma federal Resolução CONAMA 001/86.

Contudo, o estado mineiro com a DN 145 de 2009 - que regulamenta as diretrizes quanto às minerações abandonadas no estado apresenta-se mais restritivo que a norma federal e consequentemente com uma vertente protecionista mais acentuada. Tal normativa visa identificar o proponente infrator punindo-o e instituindo meios de promover a recuperação da área afetada.

No que se refere à disponibilidade e acessibilidade das normas nos sites de consulta, 0 acesso deu-se de maneira insatisfatória, exclusivamente para o portal da SEMAD, que traz suas normas aleatoriamente, não havendo 


\section{ANÁLISE DAS NORMAS AMBIENTAIS FEDERAIS E ESTADUAIS (MG e SC) REFERENTES A EMPREENDIMENTOS DE MINERAÇÃO}

organização quanto ao assunto dificultando a localização para quem busca alguma norma específica. Contudo, a Assembleia Legislativa de Minas Gerais e o Portal do SIAM, se mostraram mais organizados, levando o consultor a resultados claros e objetivos de acordo com a especificidade da busca. Da mesma forma que os sites de buscas de normas federais, verificou-se que o Princípio da Informação, um dos pilares do Direito Ambiental, está sendo cumprido em parte

Quadro 03 - Cronologia das normas legais sobre a mineração em Santa Catarina.

\begin{tabular}{|c|c|c|}
\hline Norma & Conteúdo & Fonte \\
\hline Resolução Consema no 01/2004 & $\begin{array}{l}\text { Define as atividades potencialmente } \\
\text { poluidoras, por meio de listagem, e os } \\
\text { critérios para o exercício da competência do } \\
\text { Licenciamento Ambiental Municipal. }\end{array}$ & $\begin{array}{l}\text { http://www.carvaomineral.co } \\
\text { m.br/abcm/meioambiente/legi } \\
\text { slacoes/bd_carboniferas/licenc } \\
\text { as/resolucoes_consema_01- } \\
\text { 2004.pdf }\end{array}$ \\
\hline $\begin{array}{l}\text { Resolução Consema n.․․ } \\
\text { 001/2006 }\end{array}$ & $\begin{array}{l}\text { Aprova a Listagem das Atividades } \\
\text { Consideradas Potencialmente Causadoras de } \\
\text { Degradação Ambiental passíveis de } \\
\text { licenciamento ambiental pela Fundação do } \\
\text { Meio Ambiente - FATMA e a indicação do } \\
\text { competente estudo ambiental para fins de } \\
\text { licenciamento. }\end{array}$ & $\begin{array}{l}\text { http://www.famcri.sc.gov.br/le } \\
\text { gislacao/resol_consema_2006_ } \\
\text { 1.pdf }\end{array}$ \\
\hline $\begin{array}{l}\text { Resolução Consema n.o } \\
\text { 002/2006 }\end{array}$ & $\begin{array}{l}\text { Define as atividades de impacto local para } \\
\text { fins do exercício da competência do } \\
\text { licenciamento ambiental municipal, bem } \\
\text { como os critérios necessários para o } \\
\text { licenciamento municipal por meio de } \\
\text { convênio, das atividades potencialmente } \\
\text { poluidoras previstas em listagem aprovada } \\
\text { por Resolução do CONSEMA que não } \\
\text { constituem impacto local. }\end{array}$ & $\begin{array}{l}\text { http://www.famcri.sc.gov.br/le } \\
\text { gislacao/resol_consema_2006_ } \\
\text { 2.pdf }\end{array}$ \\
\hline $\begin{array}{l}\text { Resolução Consema n.․ } \\
003 / 2008\end{array}$ & $\begin{array}{l}\text { Aprova a Listagem das Atividades } \\
\text { Consideradas Potencialmente Causadoras de } \\
\text { Degradação Ambiental passíveis de } \\
\text { licenciamento ambiental } \\
\text { pela Fundação do Meio Ambiente - FATMA e } \\
\text { a indicação do competente estudo ambiental } \\
\text { para fins de licenciamento. }\end{array}$ & $\begin{array}{l}\text { http://www.famcri.sc.gov.br/le } \\
\text { gislacao/resol_consema_2008_ } \\
\text { 3.pdf }\end{array}$ \\
\hline Resolução Consema n.o 04/2008 & $\begin{array}{l}\text { Aprova a Listagem das Atividades } \\
\text { Consideradas } \\
\text { Potencialmente Causadoras de Degradação } \\
\text { Ambiental de impacto local para fins do } \\
\text { exercício da competência do licenciamento } \\
\text { ambiental municipal. }\end{array}$ & $\begin{array}{l}\text { http://www.criciuma.sc.gov.br/ } \\
\text { arquivos/04_2008_\%20Listage } \\
\text { m_das_atividade_potencialme } \\
\text { nte_poluidoras.pdf }\end{array}$ \\
\hline Resolução Consema n.o 13/2012 & $\begin{array}{l}\text { Aprova a Listagem das Atividades } \\
\text { Consideradas Potencialmente Causadoras de } \\
\text { Degradação Ambiental passíveis de } \\
\text { licenciamento ambiental no Estado de Santa } \\
\text { Catarina e a indicação do competente estudo } \\
\text { ambiental para fins de licenciamento. }\end{array}$ & $\begin{array}{l}\text { http://www.famcri.sc.gov.br/re } \\
\text { solucoes/resol_consema13.pdf }\end{array}$ \\
\hline Resolução Consema n.o 14/2012 & $\begin{array}{l}\text { Aprova a Listagem das Atividades } \\
\text { Consideradas Potencialmente Causadoras de } \\
\text { Degradação Ambiental de impacto local para } \\
\text { fins do exercício da competência do } \\
\text { licenciamento ambiental municipal e dispõe } \\
\text { da possibilidade } \\
\text { dos Conselhos Municipais do Meio Ambiente } \\
\text { definirem outras atividades de impacto }\end{array}$ & $\begin{array}{l}\text { http://www.famcri.sc.gov.br/re } \\
\text { solucoes/resol_consema14.pdf }\end{array}$ \\
\hline
\end{tabular}


SILVA JUNIOR,L., COSTA, D.R.T.R. e ALVARENGA,M.I.N.

\section{ANÁLISE DAS NORMAS AMBIENTAIS FEDERAIS E ESTADUAIS (MG e SC) REFERENTES A EMPREENDIMENTOS DE MINERAÇÃO}

\begin{tabular}{|l|l|l|}
\hline & $\begin{array}{l}\text { local não previstas nas Resoluções do } \\
\text { Consema }\end{array}$ & \\
\hline Instrução Normativa no 16/2012 & Recuperação de Áreas Degradadas. & $\begin{array}{l}\text { http://www.fatma.sc.gov.br/sit } \\
\text { e_antigo/downloads/images/st } \\
\text { ories/Instrucao\%20Normativa/I } \\
\text { N\%2016/in_16.pdf }\end{array}$ \\
\hline Instrução Normativa no 07/2013 & Atividades de Mineração. & $\begin{array}{l}\text { http://www.fatma.sc.gov.br/sit } \\
\text { e_antigo/downloads/images/st } \\
\text { ories/Instrucao\%20Normativa/I } \\
\text { N\%2007/in_07_jun13.pdf }\end{array}$ \\
\hline
\end{tabular}

Em relação ao Estado de Santa Catarina, este apresenta um número mais elevado de normas em comparação com a União (07) e Minas Gerais (06). Atualmente encontram-se disponíveis nove (09) normas relacionadas ao setor ambiental de mineração, sendo sete (07) Resoluções do Conselho Estadual de Meio Ambiente (CONSEMA) e duas (02) Instruções Normativas (IN) da Fundação de Meio Ambiente (FATMA).

Foi instituída a Resolução CONSEMA $001 / 2004$ que trata das atividades potencialmente poluidoras e do licenciamento ambiental municipal, atribuindo competência à FATMA pelo licenciamento de tais empreendimentos. Semelhante à DN 74/04 de Minas Gerais, esta resolução traz em seu anexo as variáveis atribuídas ao porte e potencial poluidor de cada empreendimento, no qual a mineração está inserida. Entretanto, não divide em classes nem traz o tipo da mineração e qual estudo necessário como a norma mineira.

Posteriormente, em 2006, como complemento à Normativa 001/04 a Resolução CONSEMA 001/06 trouxe regulamentos sobre a indicação do tipo de estudo ambiental em relação ao porte e potencial poluidor degradador. Porém, assim como na norma mineira (DN 74/04) esta norma conflita com a federal, atribuindo a alguns tipos de empreendimentos de mineração: Relatório Ambiental Prévio (RAP) ou Estudo Ambiental Simplificado (EAS), estando apenas alguns empreendimentos passiveis de EIA/RIMA, portanto sendo mais permissiva em determinados casos. Contudo, alegam em uma de suas considerações, que a norma federal (Resolução CONAMA 001/86) não especificou profundamente a exigibilidade de EIA/RIMA, causando uma insegurança jurídica, sendo ao estado necessário criar uma lista peculiar para enquadrar os empreendimentos quanto ao porte e potencial poluidor degradador em relação aos estudos ambientais correspondentes.

No mesmo ano, a Resolução 002/06 do CONSEMA, trouxe a lista dos empreendimentos sujeitos ao licenciamento ambiental pelo município, não estando a exploração mineral inserida nos anexos, ou seja, a atividade pode ser licenciada em Santa Catarina pela FATMA quando a obra estiver exclusivamente dentro do estado, não extrapolando sua área geográfica ou pelo Instituto Brasileiro do Meio Ambiente e dos Recursos Naturais (IBAMA), quando abranger dois ou mais estados.

A Resolução CONSEMA 001/2006, foi atualizada pela Resolução CONSEMA 003/08, onde houve complementação e ajuste na lista dos empreendimentos sujeitos ao licenciamento ambiental pela FATMA e seus respectivos estudos ambientais, no qual a mineração permaneceu como na resolução anterior, sendo que alguns tipos de extração mineral ficaram sujeitos ao RAP e EAS.

As normas catarinenses, assim como as normas mineiras, apresentam significativa preocupação quanto ao grau de poluição e degradação ambiental. Com esta conotação vieram as Resoluções CONSEMA 13 e 14 de 2012 - que complementaram as Resoluções CONSEMA 01 e 02 -, se referindo às atividades com potencial degradador passíveis de licenciamento ambiental no estado e nos municípios. Entretanto, as normas de Minas Gerais caracterizam-se por singularizar normas referentes às minas abandonadas e às minas 


\section{ANÁLISE DAS NORMAS AMBIENTAIS FEDERAIS E ESTADUAIS (MG e SC) REFERENTES A EMPREENDIMENTOS DE MINERAÇÃO}

detentoras de licenças com menor grau de detalhamento, mesmo estando em desacordo, no que diz respeito à vertente protecionista, com as normas Federais, assim como se encontram na mesma situação as normas de Santa Catarina.

As duas últimas regulamentações catarinenses pesquisadas são Instruções Normativas (IN) criadas pela FATMA (16/2012, 07/2013), onde a primeira de março de 2012 refere-se ao dever de recuperação de áreas degradadas pela mineração no estado, fornecendo diretrizes para o proponente elaborar - PRAD nas especificações administrativas citadas. A segunda, IN 07/2013, refere-se às instruções gerais quanto às atividades de mineração, estando disponível em seu anexo modelos documentais para requerer as respectivas licenças.

No que se refere à disponibilidade e acessibilidade das normas nos sites de consulta, observou-se que há clareza e organização nas normas quando comparadas aos sites federal e mineiro, além de os mesmos apresentarem-se acessíveis, de modo que qualquer norma ambiental pode ser pesquisada e os resultados das buscas se dão de forma direta e em ordem cronológica. Portanto, verificou-se que o Princípio da Informação, um dos pilares do Direito Ambiental, está sendo atendido em sua totalidade.

As perspectivas encontradas nesta pesquisa indicaram uma fragilização das normas ambientais estaduais em relação à vertente protecionista, diagnosticando arranjos administrativos que simplificam os processos ambientais referentes à mineração.

Para ilustrar o que se verificou nesta pesquisa elencou-se estudos que trazem certa similaridade com os resultados aqui encontrados. Silva, Andersen e Kässmayer (2012, p. 120), chegaram a conclusões semelhantes em um estudo de avaliação comparativa de três políticas ambientais e suas normas reguladoras no estado do Paraná, onde observaram que as políticas ambientais no Brasil ainda estão relativamente à mercê do crescimento econômico.
Sousa et al. (2011, p. 748) chegaram a diagnósticos semelhantes, porém com um outro ponto de vista. Os autores verificaram a aplicabilidade da política normativa ambiental para o setor de mineração do ouro no Brasil e concluíram que a relação entre regulamento e fiscalização caminha de formas distintas, levando os agentes governamentais a criarem normas que sejam executadas de maneira mais cômoda, ou seja, a mineração possui compromissos legais irrelevantes do ponto de vista ecológico.

Chang, Sigman e Traub (2014, p. 49), realizaram um estudo nos Estados Unidos analisando a descentralização das políticas normativas ambientais federais e diagnosticaram que os Estados buscam por meio de autorizações ambientais regerem políticas mais rígidas do que as encontradas em âmbito Federal, que normalmente formulam políticas básicas para manter a qualidade ambiental no País, e sendo assim, cabe ao estado inferir as melhores adequações ambientais. Em contrapartida os países Asiáticos, tendem a reformular suas regulamentações quanto às questões ambientais para os empreendimentos de mineração, já que a relação custo e benefício (ambiental) já não está sendo tão positiva. Com isso os governos Asiáticos estudam a reformulação das políticas ambientais para o setor mineral, e instruem a adaptação dos empreendimentos para as novas regulamentações ambientais (OTTO; NAITO; PRING, 1999, p. 332).

Contudo, Dimitrov (2010, p. 40), em seu estudo sobre as políticas ambientas globais chegou à conclusão de que a criação de políticas ambientais mais responsáveis e coerentes com a demanda peculiar da região - e consequentemente de normas específicas para cada caso -, deve abranger conhecimentos ecológicos por cientistas das áreas afins e promover meios de nortear o desenvolvimento verdadeiramente sustentável. Complementar à tal perspectiva, Fikru (2013, p. 457) diz que as políticas ambientais devem ser flexíveis o suficiente para garantir o bem-estar que gira ao redor do mundo financeiro e garantir a preservação ambiental. De tal maneira, verifica- 


\section{ANÁLISE DAS NORMAS AMBIENTAIS FEDERAIS E ESTADUAIS (MG e SC) REFERENTES A EMPREENDIMENTOS DE MINERAÇÃO}

se que a adaptabilidade de normas deve ocorrer em todas as jurisdições, já que a mesma diferencia-se a nível ambiental de todo território nacional, como observado em Minas Gerais e Santa Catarina.

\section{CONCLUSÕES}

Para o melhor entendimento do que foi trabalhado, cabe relembrar que a CF traz em seu artigo 22, que é competência privativa da União legislar sobre a exploração dos recursos minerais, sendo que esta exploração pode ser delegada aos estados. Portanto pode a União e os Estados legislarem sobre exploração de recursos minerais.

Mas, no que se refere à proteção dos recursos naturais - nestes incluídos os recursos minerais - a CF traz em seu artigo 24 que a competência legislativa é concorrente, ou seja tanto a União quanto os Estados podem legislar sobre proteção ambiental. Mas para evitar insegurança jurídica, cabe a União trazer normas mais gerais sobre o tema, sendo que os estados não podem editar normas mais permissivas que as federais.

Com base neste raciocínio, as normas ambientais federais relacionadas a empreendimentos de mineração são significativamente genéricas e quantitativamente reduzidas, já que as diretrizes ambientais estão acopladas à regulamentações de licenciamento e estudos de impacto ambiental, não inferindo procedimentos específicos às mineradoras.

Entretanto, de modo geral, as normas Federais são bem explícitas quanto às ações administrativas e penalidades, tanto para o processo de licenciamento ambiental, quanto para as infrações operacionais. Pode-se verificar qualitativamente que as diretrizes ambientais federais, quanto aos processos de licenciamento e avaliação de impacto ambiental, são bem claras e objetivas enquadrando todos os empreendimentos de mineração à necessidade do licenciamento ambiental e EIA/RIMA, além de obrigar os proponentes a recuperarem as áreas degradadas pós-garimpagem.
Em Minas Gerais, mesmo sendo o estado com maior extração mineral do país, verificou-se um número inferior de normas quando comparados à Federação e o estado Catarinense, o que sugere um déficit de abrangência de normas já que o estado contempla a maior diversidade mineral do país, impactando diversos ecossistemas distintos, aqui cabendo um questionamento: número de normas reflete em qualidade de normas? Entretanto, o estado apresenta normas singulares como as DN's 127 e 145 que tratam especificamente do PRAD e identificação e classificação de minerações abandonadas respectivamente. Porém, quanto à análise qualitativa, verificou-se que o estado, enquadrou suas atividades potencialmente poluidoras degradadoras em seis classes distintas em relação ao licenciamento e estudos de impacto ambiental. No entanto, a extração mineral foi mesclada nestas classes, sendo alguns tipos de extrações passiveis de AAF e EAS, o que conflitam diretamente com a regulamentação Federal 001/86, fato que acaba por deixar a proteção ambiental vulnerável, ou seja, são normas mais permissivas que as federais

Já o estado de Santa Catarina, apresentou-se quantitativamente superior à União e Minas Gerais, porém a maioria de suas normas são atualizações de normas já existentes. Contudo, assemelham-se muito às mineiras, sobretudo, na distinção das classificações quanto ao potencial poluidor degradador. Entretanto, esperava-se mais restrições em Minas Gerais, por apresentar uma demanda de extração mineral muito superior à encontrada em Santa Catarina, onde prevalece apenas a exploração de carvão.

Desta maneira, observou-se conflitos normativos no que se refere à vertente protecionista, principalmente em relação aos trâmites do licenciamento ambiental. As fragilidades encontradas convergem pelo favorecimento econômico e crescimento financeiro da região, o que consequentemente prejudica os aspectos ambientais e culminam em severos impactos tanto no meio biótico e abiótico, quanto no meio social que, muitas vezes, é indiretamente afetado pela implantação 


\section{ANÁLISE DAS NORMAS AMBIENTAIS FEDERAIS E ESTADUAIS (MG e SC) REFERENTES A EMPREENDIMENTOS DE MINERAÇÃO}

destes empreendimentos com características singulares, quanto às emissões de particulados poluidores, degradação do solo, contaminação aquática, perda de biodiversidade e diversos outros impactos.

\section{REFERÊNCIAS}

ALEXANDRE, N. Z. Diagnóstico ambiental da Região carbonífera de Santa Catarina: Degradação dos recursos naturais. Revista Tecnologia e Ambiente, Criciúma - SC, v.5, n.2, p.35-50, 1999.

AMARAL, J. E.; CANCELIER, T. S.; KREBS, A. S. J.; RODRIGUES G. T. Mitigação ambiental de áreas degradadas pela mineração de carvão em Santa Catarina. In: CONGRESSO BRASILEIRO DE CARVÃO MINERAL, III, 2011, Gramado - RS: ABCM, 21 ago. 2011, p. 1-17.

ASSIS, M. P.; MALHEIROS, T. F.; FERNANDES, V.; PHILIPPI JR. A. Avaliação de Políticas Ambientais: desafios e perspectivas. Revista Saúde e Sociedade, São Paulo, v.21, supl.3, p.7-20, 2012.

BACCI, D. L. C.; LANDIM, P. M. B.; ESTON, S. M. Aspectos e impactos ambientais de pedreira em área urbana. Revista Escola de Minas, Ouro Preto - MG, v. 59, n. 1, p. 47-54, 2006.

BANDERIA, A. P. F. Custos ambientais na análise de viabilidade econômica de projetos de mineração: aplicação em área carbonífera do estado de Santa Catarina. Nov. 2006. Dissertação (Mestrado). Programa de Recursos Hídricos e Saneamento Ambiental, Universidade Federal do Rio Grande do Sul, Porto Alegre - RS.

BORGES, L. A. C.; REZENDE, J. L. P.; PEREIRA, J. A. A.; Evolução da Legislação Florestal no Brasil. Revista em Agronegócios e Meio Ambiente, Maringá - PR, v. 2, n. 3, p. 447-466, 2009.

BRASIL. Decreto Lei Federal № 227, de 28 de fevereiro de 1967. Dispõe sobre o Código Nacional de Mineração. Diário oficial da União, Brasília, 28 fev. 1967.

BRASIL. Constituição da República Federativa do Brasil de 1988. Diário Oficial da União, Brasília, 05 out. 1988.

BRASIL. Decreto № 97.507, de 13 de fevereiro de 1989. Dispõe sobre licenciamento de atividade mineral, o uso do mercúrio metálico e do cianeto em áreas de extração de ouro, e dá outras providências. Diário Oficial da União, Brasília,14 fev. 1989.

BRASIL. Decreto № 97.632, de 10 de abril de 1989. Dispõe sobre a regulamentação do Artigo $2^{\circ}$, inciso VIII, da Lei $n^{\circ} 6.938$, de 31 de agosto de 1981, e dá outras providências. Diário Oficial da União, Brasília, 12 abr. 1989.

BRASIL. Lei № 7.805, de 18 de julho de 1989. Altera o Decreto-Lei no 227, de 28 de fevereiro de 1967, cria o regime de permissão de lavra garimpeira, extingue o regime de matrícula, e dá outras providências. Diário Oficial da União, Brasília, 20 jul. 1989.

BRASIL. Lei № 11.685, de 2 de junho de 2008. Institui o Estatuto do Garimpeiro e dá outras providências. Diário Oficial da União, Brasília, 3 jun. 2008.

CHANG, H.; SIGMAN, H.; TRAUB, L. G. Endogenous Decentralization in Federal Environmental Policies. International Review of Law and Economics, Saint Louis - EUA, v. 27, p. 39-50, 2014.

CONAMA - Conselho Nacional de Meio Ambiente, Resolução № 001, de 23 de janeiro de 1986. Dispõe sobre critérios básicos e diretrizes gerais para a avaliação de impacto ambiental. Diário Oficial da União, Brasília, 17 de fevereiro de 1986.

CONAMA - Conselho Nacional de Meio Ambiente (Brasil). Resolução № 237, de 19 de dezembro de 1997. Dispõe sobre a revisão e complementação dos procedimentos e critérios utilizados para o licenciamento ambiental. Diário Oficial da União, Brasília, 19 dez. 1997.

CONSEMA - Conselho Estadual de Meio Ambiente (Santa Catarina). Resolução № 01/2004. Define as atividades potencialmente poluidoras, por meio de listagem, e os critérios para o exercício da competência do Licenciamento Ambiental Municipal. Florianópolis, 24 set. 2004.

CONSEMA - Conselho Estadual de Meio Ambiente (Santa Catarina). Resolução N.o 001/2006 - Aprova a Listagem das Atividades Consideradas Potencialmente Causadoras de Degradação Ambiental passíveis de 


\section{ANÁLISE DAS NORMAS AMBIENTAIS FEDERAIS E ESTADUAIS (MG e SC) REFERENTES A EMPREENDIMENTOS DE MINERAÇÃO}

licenciamento ambiental pela Fundação do Meio Ambiente - FATMA e a indicação do competente estudo ambiental para fins de licenciamento. Florianópolis, 20 jul. 2007.

CONSEMA - Conselho Estadual de Meio Ambiente (Santa Catarina). Resolução N.o 002/2006 - Define as atividades de impacto local para fins do exercício da competência do licenciamento ambiental municipal, bem como os critérios necessários para o licenciamento municipal por meio de convênio, das atividades potencialmente poluidoras previstas em listagem aprovada por Resolução do CONSEMA que não constituem impacto local. Florianópolis, 20 jul. 2007.

CONSEMA - Conselho Estadual de Meio Ambiente (Santa Catarina). Resolução N.o 003/2008 - Aprova a Listagem das Atividades Consideradas Potencialmente Causadoras de Degradação Ambiental passíveis de licenciamento ambiental pela Fundação do Meio Ambiente - FATMA e a indicação do competente estudo ambiental para fins de licenciamento. Florianópolis, 13 mai. 2008.

CONSEMA - Conselho Estadual de Meio Ambiente (Santa Catarina). Resolução N.o 04/2008 - Aprova a Listagem das Atividades Consideradas Potencialmente Causadoras de Degradação Ambiental de impacto local para fins do exercício da competência do licenciamento ambiental municipal. Florianópolis, 29 abr. 2008.

CONSEMA - Conselho Estadual de Meio Ambiente (Santa Catarina). Resolução N.o 13/2012 - Aprova a Listagem das Atividades Consideradas Potencialmente Causadoras de Degradação Ambiental passíveis de licenciamento ambiental no Estado de Santa Catarina e a indicação do competente estudo ambiental para fins de licenciamento. Florianópolis, 21 dez. 2012.

CONSEMA - Conselho Estadual de Meio Ambiente (Santa Catarina). Resolução N.o 14/2012 - Aprova a Listagem das Atividades Consideradas Potencialmente Causadoras de Degradação Ambiental de impacto local para fins do exercício da competência do licenciamento ambiental municipal e dispõe da possibilidade dos Conselhos Municipais do Meio Ambiente definirem outras atividades de impacto local não prevista nas Resoluções do CONSEMA. Florianópolis, 21 dez. 2012.

COPAM. Conselho Estadual de Política Ambiental (Minas Gerais). Deliberação Normativa $n^{\circ} 074$ de 09 de setembro de 2004. Estabelece critérios para classificação, segundo o porte e potencial poluidor, de empreendimentos e atividades modificadoras do meio ambiente passíveis de autorização ou de licenciamento ambiental no nível estadual, determina normas para indenização dos custos de análise de pedidos de autorização e de licenciamento ambiental, e dá outras providências. Belo Horizonte, 02 out. 2004.

COPAM. Conselho Estadual de Política Ambiental (Minas Gerais). Deliberação Normativa № 127, de 27 de novembro de 2008. Estabelece diretrizes e procedimentos para avaliação ambiental da fase de fechamento de mina. Belo Horizonte, 29 nov. 2008.

COPAM. Conselho Estadual de Política Ambiental (Minas Gerais). Deliberação Normativa № 144, de 18 de dezembro de 2009. Dispõe sobre a declaração de informações relativas à identificação e classificação de áreas mineradas detentoras de Autorização Ambiental de Funcionamento - AAF no Estado de Minas Gerais. Belo Horizonte, 15 jan. 2010.

COPAM. Conselho Estadual de Política Ambiental (Minas Gerais). Deliberação Normativa № 145, de18 de dezembro de 2009 - Dispõe sobre a declaração de informações relativas à identificação e classificação de áreas mineradas abandonadas no Estado de Minas Gerais. Belo Horizonte, 15 jan. 2010.

DIMITROV, R. S. Precaution in Global Environmental Politics. Desenvolvimento e Meio Ambiente, Curitiba - PR, v. 21, p. 27-42, 2010.

FABRI, E. S.; CARNEIRO, M. A.; LEITE, M. G. P. Diagnóstico dos processos de licenciamento e fiscalização das pedreiras de rochas ornamentais na região centro-sul de Minas Gerais. Revista Escola de Minas. Ouro Preto - MG, v. 61, n. 3, p. $279-284,2008$. 


\section{ANÁLISE DAS NORMAS AMBIENTAIS FEDERAIS E ESTADUAIS (MG e SC) REFERENTES A EMPREENDIMENTOS DE MINERAÇÃO}

FARIAS, C.E.G. Mineração e meio ambiente no Brasil. Centro de Gestão e Estudos Estratégicos. Ciência, Tecnologia e Inovação. CGEE. 2002. 42p. Disponível

em: (http://www.cgee.org.br/arquivos/estudo011_02 .pdf). Acesso em: (12 abr. 2015).

FATMA - Fundação do Meio Ambiente (Santa Catarina). Instrução Normativa № 16/2012. Recuperação de Áreas Degradadas. Florianópolis, 21 mar. 2012.

FATMA - Fundação do Meio Ambiente (Santa Catarina). Instrução Normativa № 07/2013. Atividades de Mineração. Florianópolis, 24 jun. 2013.

FEAM - Fundação Estadual de Meio Ambiente. Inventário de áreas impactadas pela mineração do estado de Minas Gerais. Diretoria de Gestão e Qualidade Ambiental, Gerência de Qualidade do Solo e Reabilitação de Áreas Degradadas. Belo Horizonte - MG, 53 p., 2011. Disponível em: (http://www.feam.br/images/stories/inventario/i nventario_final_12_12.pdf). Acesso em: (17 maio 2015).

FIESC - Federação das Indústrias do Estado de Santa Catarina. Santa Catarina em Dados. 23 ed. Florianopolis - SC, 176 p. 2013. Disponível em: (http://fiesc.com.br/sites/default/files/medias/sc _em_dados_2013_pdf). Acesso em: (25 maio 2015).

FIKRU, M. G. Environmental Policies, Mergers and Welfare. Economía Mexicana Nueva Época, Cidade do México, v. 22, n. 2, p. 449-461, 2013.

GERÔNIMO, V. A extração do carvão na região carbonífera do sul de Santa Catarina e suas consequências negativas. 26 ago. 2004. Monografia (Pós-graduação em Solos e Meio Ambiente). Departamento de Ciências do Solo, Universidade Federal de Lavras - UFLA, Lavras MG.

GIL, A. C. Métodos e técnicas de pesquisa social. São Paulo - SP: Atlas, 2008.

GUIMARÃES, J. C. C.; CHAGAS, J. M.; CAMPOS, C. C. F.; ALECRIM, E. F.; MACHADO, F. S. Avaliação dos aspectos e impactos ambientais decorrentes da mineração de bauxita no sul de Minas Gerais. Enciclopédia Biosfera, Goiânia - GO, v. 8, n. 15, p. $321-333,2012$.
IBAMA - Instituto Brasileiro do Meio Ambiente e dos Recursos Renováveis. Geo Brasil 2002 Perspectivas do Meio Ambiente no Brasil. Brasília - DF, 475 p., 2002. Disponível em: (http://www.ibama.gov.br/sophia/cnia/site_cnia /geo_brasil_2002.pdf). Acesso em: (13 maio 2015).

IBRAM - Instituto Brasileiro de Mineração. Informações sobre a economia mineral no estado de Minas Gerais. 7ạ ed. 17 p. jan. 2014. Disponível em: (http://www.ibram.org.br/sites/1300/1382/0000 3791.pdf). Acesso em: (14 abr. 2015).

IBRAM - Instituto Brasileiro de Mineração. Informações e análises da economia mineral brasileira. 7a ed. 68 p. dez. 2012. Disponível em: (http://www.ibram.org.br/sites/1300/1382/0000 2806.pdf). Acesso em: (14 abr. 2015).

KAUARK, F. S.; MANHÃES, F. C; MEDEIROS, C. H. Metodologia da pesquisa: Um guia prático. Itabuna - BA: Via Litterarum, 2010.

MINAS GERAIS. Lei № 10.595, de 07 de janeiro de 1992. Proíbe a utilização de mercúrio e cianeto de sódio nas atividades de pesquisa mineral, lavra e garimpagem nos rios e cursos de água do Estado e dá outras providências. Belo Horizonte, 8 jan. 1992.

MINAS GERAIS. Decreto № 44.309, de 5 de junho de 2006. Estabelece normas para o licenciamento ambiental e a autorização ambiental de funcionamento, tipifica e classifica as infrações às normas de proteção ao meio ambiente e aos recursos hídricos e estabelece o procedimento administrativo de fiscalização e aplicação das penalidades. Belo Horizonte, 6 jun. 2006.

MILANI, C. R. S. Políticas públicas locais e participação na Bahia: o dilema gestão versus política. Revista Sociologias, Porto Alegre - RS, ano 8, n. 16, p. 180-214, 2006.

MICKWITZ, P. Environmental policy evaluation. Concepts and practice. Helsinki: Finnish Society of Sciences and Letters, 2006.

MONTEIRO, K. V. Carvão: o combustível de ontem. Porto Alegre - RS: Núcleo amigos da terra Brasil, 2004.

OTTO, J.; NAITO, K.; PRING, G. Environmental regulation of exploration and mining operations 


\section{ANÁLISE DAS NORMAS AMBIENTAIS FEDERAIS E ESTADUAIS (MG e SC) REFERENTES A EMPREENDIMENTOS DE MINERAÇÃO}

in Asian countries. Natural Resources Forum, Malden - EUA, v. 23, n. 4, p. 323-334, 1999.

PHILOMENA, G. L. B.; FOLLMANN, J. I.; GONÇALVES, T. M. Aspectos da cultura do carvão em Criciúma (SC): a história que não se conta. Revista História Unisinos. São Leopoldo - RS, v. 16, n. 2, p. $244-255,2012$.

RODRIGUES, M. L.; MALHEIROS, T. F.; FERNANDES, V.; DARÓS, T. D. A Percepção Ambiental Como Instrumento de Apoio na Gestão e na Formulação de Políticas Públicas Ambientais. Revista Saúde e Sociedade, São Paulo, v.21, supl.3, p.96-110, 2012.

SÁNCHEZ, L.H. Avaliação de impacto ambiental: Conceitos e métodos. São Paulo - SP: Oficina de Textos, 2013.

SANTOS, W. F. S.; CARVALHO, I. S.; FERNANDES, A. C.S. Mineração versus Paleontologia: Uso e Ocupação da Serra do Veadinho em Peirópolis Uberaba, Estado de Minas Gerais (Brasil). Anuário do Instituto de Geociências - UFRJ. Rio de Janeiro - RJ, v. 33, n. 2, p. $74-86,2010$

SILVA, C. L.; ANDERSEN, S.; KÄSSMAYER, K. Comparative Evaluation of Three Environmental Policies in Paraná State: the EEZ, the GERCO and Incentive Policies to Agroecology. Revista Paranaense de Desenvolvimento. Curitiba - PR, n.122, p.95-122, 2012.

SOUZA SILVA, J. P. Impactos ambientais causados por mineração. Revista Espaço da Sophia, ano 1, n. 8, 13 p., 2007. Disponível em: (http://www.registro.unesp.br/sites/museu/base dedados/arquivos/00000429.pdf). Acesso em: (10 mar. 2015).

SOUSA, R.; VEIGA, M.; ZYL, D. V.; TELMER, K.; SPIEGEL, S.; SELDER, J. Policies and regulations for Brazil's artisanal gold mining sector: analysis and recommendations. Journal of Cleaner Production, v. 19, p. 742-750, 2011

SOUZA, D, I.; MULLER, D. M.; FRACASSI, M. A. T.; ROMEIRO, S. B. B. Manual de orientações para projetos de pesquisa. Novo Hamburgo - RS: Fundação Escola Técnica Liberato Salzano Vieira da Cunha, 2013.

TONIDANDEL, R. P. PARIZZI, M. G.; LIMA, H. M. Aspectos legais e ambientais do fechamento de mina, com ênfase no estado de Minas Gerais.
Geonomos, Belo Horizonte - MG, v. 20, n. 1, p. 32-40, 2012.

UBALDO, M. O.; SOUZA, V. P. Controle e mitigação dos impactos da drenagem ácida em operações de mineração. In: SOARES, P. S. M.; SANTOS, M. D. C.; POSSA, M. V. Carvão Brasileiro: tecnologia e meio ambiente. Rio de Janeiro, CETEM/MCT, 2008. p. 129-151. Disponível em: (http://www.cetem.gov.br/publicacao/CTs/CT20 08-024-00.pdf). Acesso em: (07 mar. 2015).

VIANA, M. B.; BURSZTYN, M. A. A. Regularização ambiental de minerações em Minas Gerais. Revista Escola de Minas. Ouro Preto, v. 63, n. 2, p. 363-369, 2010.

YAMAGUCHI, C. K.; SORATTO, K. A. D. L.; MARIOT, M. G. Aplicabilidade do termo de ajustamento de conduta (TAC) em uma indústria carbonífera de Santa Catarina e o impacto na contabilidade e no orçamento organizacional. Revista Ambiente Contábil. Natal - RN, v. 6, n. 2, p. 220 - 239, 2014.

WATHERN, P. Environmental impact assessment: Theory and practice. London: Routledge, 1988.

WEI, $X$; VIADERO Jr. R.C.; BHOJAPPA, S. Phosporus removal by acid mine drainage sludge from secondary effluents of municipal wastewater treatment plants. Water Research, v. 42 , p. $3275-3284,2008$ 